\title{
Pengaruh Pupuk Hayati Dan Pupuk NPK Untuk Meningkatkan Pertumbuhan Tanaman Tomat (Solanum lycopersicum) Yang Di Tanam Pada Tanah Terinfeksi Fusarium Oxysporum.
}

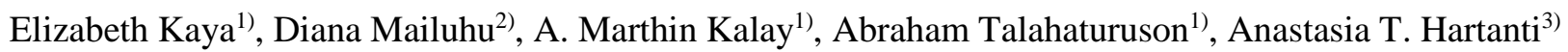 \\ ${ }^{1)}$ Dosen Program Studi Pengelolaan Lahan, Program Pascasarjana, Universitas Pattimura \\ ${ }^{2)}$ Alumni Program Studi Pengelolaan Lahan, Program Pascasarjana, Universitas Pattimura \\ ${ }^{3)}$ Dosen Fakultas Teknobiologi, Universitas Katolik Indonesi Atma Jaya \\ Email: elizabethkaya712@gmail.com
}

\begin{abstract}
ABSTRAK
Salah satu penyakit pada tanaman tomat adalah layu oleh serangan Fusarium oxysporum. Pengendalian secara hayati dan pengelolaan kesuburan tanah merupakan pilihan yang efisien. Upaya peningkatkan kesuburan tanah adalah dengan cara pemupukan dengan pupuk organik dan pupuk anorganik. Penelitian ini bertujuan untuk mengkaji dan mendapatkan dosis kompos ela sagu yang diperkaya dengan Trichoderma dan Azotobacter (KESTA) dan diberi bersama-sama dengan pupuk organik cair (POC) atau NPK untuk meningkatkan pertumbuhan tanaman tomat pada tanah terinfeksi patogen Fusarium oxysporium dipersemaian maupun dipot. Perlakuan yang dicobakan adalah dosis $\operatorname{KESTA}\left(\mathrm{K}_{0}=\right.$ Tanpa KESTA, $\mathrm{K}_{1}=15$ ton KESTA ha ${ }^{-1}, \mathrm{~K}_{2}=30$ ton KESTA ha ${ }^{-1}, \mathrm{~K}_{3}=45$ ton KESTA ha $\left.{ }^{-1}\right)$ dan dua jenis pupuk yaitu: $\left(\mathrm{P}_{0}=\right.$ Tanpa Pupuk, $\mathrm{P}_{1}=$ Pupuk organik cair (POC) $10 \mathrm{~mL} \mathrm{~L}^{-1} \mathrm{P}_{2}=$ Pupuk NPK $1.000 \mathrm{~kg} \mathrm{ha}^{-1}$ ). Penelitian ini dirancang menggunakan Rancangan Acak Lengkap. Hasil penelitian menunjukkan bahwa: 1. Aplikasi KESTA dan pupuk (POC dan NPK) memberikan pengaruh terhadap intensitas penyakit layu, tinggi tanaman, bobot segar dan bobot kering tanaman pada umur 28 hari setelah tanam dipersemaian; dan tinggi tanaman pada umur 35 hari setelah tanam pada tanaman tomat dipot. 2. Dosis KESTA yang paling efektif adalah 45 ton ha ${ }^{-1}$, karena dapat menekan intensitas layu sampai 61,92 \%. Sedangkan Jenis pupuk NPK dan POC masing-masing dapat menekan intensitas penyakit sebesar 23,08 \% dan 13,32\%. 3. Pemberian KESTA 45 ton/ha lebih efektif jika diberikan dengan POC maupun NPK, diperlihatkan dengan meningkatnya tinggi tanaman, bobot segar dan bobot kering tanaman pada umur 28 hari setelah tanam dipersemaian, dan tinggi tanaman pada umur 35 hari setelah tanam dipot.
\end{abstract}

Kata Kunci : Pupuk Hayati; Trichoderma harzianum dan Azotobacter chroococcum; Tanaman Tomat, layu Fusarium

\section{Effects of Biofertilizer and NPK Fertilizer to Increase the Growth of Tomato (Solanum lycopersicum) Planted In Fusarium oxysporum Infected Soils}

\begin{abstract}
One of the tomato plants diseases is wilting due to Fusarium oxysporum attack. Biological control and management of soil fertility are efficient options. Efforts to increase soil fertility are using organic and inorganic fertilizers. This study aims to assess and obtain doses of sago ela compost added by Trichoderma and Azotobacter (KESTA) and organic liquid fertilizer (POC) or NPK to increase tomato plants growth on pathogen Fusarium oxysporium infectedsoil both on nurseries and pots. The treatments tested were the dose of KESTA (K0 = Without KESTA, K1 $=15$ tons of KESTA ha-1, K2 = 30 tons of KESTA ha-1, K3 = 45 tons of KESTA ha-1) and two types of fertilizers, namely: (P0 = Without Fertilizer, P1 = liquid organic fertilizer $(\mathrm{POC}) 10 \mathrm{~mL} \mathrm{~L}-1 \mathrm{P} 2=$ NPK fertilizer 1,000 kg ha-1). This study was designed using a completely randomized design. The results showed that (1) the application of KESTA and fertilizers (POC and NPK) effects the wilt disease intensity, plant height, plant fresh and dry weight at the age of 28 days after planting; and the plant height at the age of 35 days after planting, (2) The most effective dose of KESTA is 45 tons ha-1, because it can reduce the intensity of withering up to $61.92 \%$. Meanwhile, the types of NPK and POC fertilizers could reduce the intensity of the disease by $23.08 \%$ and $13.32 \%$, respectively, (3) the application KESTA of 45 ton / ha is more effective if given with POC or NPK, as shown by the increasing in plant height, fresh and dry weight at the age of 28 days after planting in the nursery, and plant height at the age 35 days after planting in pot.
\end{abstract}

Keywords: Biofertilizer, Trichoderma harzianum, Azotobacter chroococcum, Tomat, Fusarium wilt 
Kaya et al, 2020. Pengaruh Pupuk Hayati ...

\section{PENDAHULUAN}

Tanaman tomat (Lycopersicon esculentum) menghasilkan buah yang mengandung banyak zat - zat penting seperti protein, lemak, gula (glukosa dan fruktosa), kholoin, histamin, dan vitamin ${ }^{[1]}$. Produksi tanaman tomat di provinsi Maluku sering mengalami fluktuasi. Produksi tanaman tomat pada tahun 2013 dengan data produksi 4.422 Ton dan luas panen $771 \mathrm{Ha}$, tahun 2014 data produksi 3.288 Ton dan luas panen $715 \mathrm{Ha}$, dan tahun 2015 data produksi 3.368 Ton dan luas panen 680 ha ${ }^{[2]}$.

Upaya peningkatan produksi tanaman tomat terkendala masalah kondisi kesuburan tanah dan kerusakan tanaman akibat terserang penyakit. Salah satu upaya untuk meningkatkan kesuburan tanah adalah dengan pemupukan baik pupuk organik dan pupuk anorganik ${ }^{[3]}$. Kesuburan tanah adalah suatu keadaan tanah dimana tata air, udara dan unsur hara dalam keadaan cukup seimbang dan tersedia sesuai kebutuhan tanaman, baik fisik, kimia dan biologi tanah ${ }^{[4]}$.

Bahan organik merupakan salah satu pembenah tanah yang telah dirasakan manfaatnya dalam perbaikan sifat-sifat tanah baik sifat fisik, kimia dan biologi tanah. Peranan kompos secara umum berdampak baik terhadap sifat dan karakteristik biogeofisik tanah. Pemberian kompos ela sagu 15 ton $\mathrm{ha}^{-1}$ dapat meningkatkan $\mathrm{pH}$ tanah, Fosat tersedia, serapan fosfat, dan berat pipilan kering jagung [5]. Kompos yang dapat meningkatkan produksi kacang tanah ${ }^{[6]}$ dan sawi [7]. Dosis pupuk organik berbasis Trichoderma 30 ton/ha dapat memberikan hasil yang signifikan bagi pertumbuhan dan hasil tanaman ${ }^{[8]}$. Selain kompos, pupuk organik cair (POC) yang diberikan ke tanah berperan memperbaiki sifat fisik dan kimia tanah, serta` meningkatkan serapan unsur hara oleh tanaman. Kombinasi dosis pupuk hayati $10 \mathrm{~mL} /$ tanaman dengan media tanam kompos memberikan hasil produksi (berat buah) terbaik sebesar 128,59 g/tanaman pada tanaman tomat ${ }^{[9]}$.
Mengingat ketersediaan pupuk kimia pada saat sekarang ini semakin sulit, dan harganya semakin mahal, maka penggunaannya harus diusahakan seefisien mungkin. Pemupukan yang kurang dari kebutuhan tanaman menjadikan tidak optimalnya produksi. Pupuk NPK merupakan pupuk majemuk bebentuk butiran yang mengandung unsur hara, nitrogen, fospor dan kalium. Rekomemdasi pupuk majemuk NPK 15-15-15 dengan dosis 1.000-1.200 kg/ha $[10,11]$

Salah satu penyakit yang sering ditemukan di areal pertanaman tomat adalah penyakit layu fusarium disebabkan oleh jamur Fusarium oxysporum. Penykit ini merupakan penyakit yang sangat penting dan secara ekonomi merugikan. Pengendalian secara hayati dan pengelolaan kesuburan tanah merupakan pilihan yang efisien untuk mengendalikan penyakit ini ${ }^{[12]}$.

Penggunaan agens hayati bertujuan untuk mengurangi kemampuan bertahan suatu patogen, menghambat pertumbuhan dan penyebaran, mengurangi infeksi akibat serangan patogen pada tanaman inang. Penggunaan mikroorganisme yang bersifat antagonis terhadap patogen tular tanah adalah Trichoderma ${ }^{[13]}$. Jamur $T$. harzianum dapat menurunkan persentase penyakit layu fusarium pada tanaman tomat sampai $100 \%$ di dalam rumah kaca ${ }^{[14]}$, dapat mengendalikan patogen Rhizoctonia solani ${ }^{[15]}$, Phytopthora palmivora pada bibit kakao ${ }^{[16]}$ dan nematoda Globodera rostochiensis pada tanaman kentang ${ }^{[17]}$. Aplikasi jamur Trichoderma spp dalam skala yang lebih luas diperlukan perbanyakan dengan menggunakan bahan organik, seperti kompos, pupuk kandang dan limbah pertanian. Bahan organik seperti campuran ela sagu dengan dedak, dan campuran ela sagu dengan kompos dapat dimanfaatkan sebagai media produksi maupun media perbanyakan Trichoderma ${ }^{[18,19,20]}$.

Azotobacter adalah satu jenis bakteri aerobik gram negatif yang berperan sebagai penghambat $\mathrm{N}_{2}$ di perakaran tanaman [21]. Azotobacter chroococcum mampu mem- 
produksi hormon sitikinin, memproduksi eksopolisakarisa (EPS), memfiksasi $\mathrm{N}_{2}$, meningkatkan aktifitas enzin nitrogenase, hormon IAA (Indole Aceti Acid), Giberelin, dan sebagai agens hayati pengendali patogen pada tanaman sayuran ${ }^{[22]}$. Selain peranannya dalam meningkatkan pertumbuhan, bakteri $A$. chroococcum dapat menghasilkan metabolit sekunder dan zat anti mikroba yang memiliki aktivitas antagonis terhadap jamur fitopatogenik dan bakteri yang menyebabkan penyakit pada tanaman [23]. Beberapa hasil penelitian menunjukkan bahwa $A$. chroococcum mampu menurunkan intensitas penyakit hawar daun yang disebabkan oleh $R$. Solani sebessar $25,64 \%$ pada tanaman sawi ${ }^{[7]}$.

Penggunaan pupuk hayati meningkatkan kandungan hara tanah sehingga mengurangi penggunaan pupuk anorganik. Kombinasi pupuk anorganik dan organik merupakan perlakuan yang paling efektif untuk mencapai pertumbuhan dan hasil yang optimal dalam budidaya tomat ${ }^{[24]}$.

Berdasarkan konsep pemikiran tersebut di atas maka perlu melakukan penelitian dengan tujuan untuk mendeskripsikan respons tanaman tomat terhadap penambahan KESTA jika diaplikasikan dengan pupuk organik cair (POC) atau pupuk NPK yang ditanaman pada tanah terinfeksi patogen Fusarium oxysporium di pesemaian dan di pot.

\section{BAHAN DAN METODE}
Penelitian ini dilakukan di rumah plastik Fakultas Pertanian Universitas Pattimura Ambon. Pengamatan mikroskopik penyebab penyakit dilakukan di Laboratorium Penyakit Tumbuhan Fakultas Pertanian mulai dari bulan Maret sampai Mei 2017. Menggunakan bibit tomat varietas Permata F1, isolat $F$. oxysporum, kompos ela sagu yang diperkaya dengan inokulan Trichoderma hrzianum dan Azotobacter chrococcum

(KESTA), tanah regosol, pupuk organik cair (POC), pupuk NPK Ponska dan potato dextrose agar (PDA).

Penelitian ini dirancang menggunakan Rancangan Acak Lengkap (RAL) pola faktorial, yang terdiri dari dua factor. Faktor pertama adalah KESTA, dengan 4 taraf dosis yaitu : $\mathrm{K}_{0}=$ tanpa KESTA, $\mathrm{K}_{1}=15$ ton KESTA ha ${ }^{-1}, \mathrm{~K}_{2}=30$ ton KESTA ha ${ }^{-1}$, dan $\mathrm{K}_{3}=45$ ton KESTA ha ${ }^{-1}$, serta Faktor kedua adalah pupuk, yaitu : $\mathrm{P}_{0}=$ Tanpa Pupuk, $\mathrm{P}_{1}=$ POC $(0,1 \%)$, dan $\mathrm{P}_{2}=$ Pupuk NPK $(1.000 \mathrm{~kg}$ $\left.\mathrm{ha}^{-1}\right)$. Hasil penelitian dianalisis dengan menggunakan analisis ragam dan uji lanjut menggunakan uji Jarak Berganda Duncan (DMRT) pada taraf 5\%, menggunakan software SigmaStat.

\section{HASIL DAN PEMBAHASAN}

\section{Gejala Penyakit}

Hasil pengamatan gejala penyakit secara visual terhadap bibit tomat di pesemaian, terlihat bahwa pada bagian pangkal batang berwarna cokelat, warna daun menguning atau layu, sedangkan pada percobaan pot tidak terlihat adalah tanaman yang sakit (Gambar 1). Deskripsi gejala penyakit seperti ini juga terjadi pada penelitian lainnya yaitu bahwa tanaman infeksi pada umur muda, tulang daun dari tanaman terinfeksi mengalami pemucatan dan berwarna keputihan, tanaman terkulai karena penyerapan unsur hara dan air terhambat yang disebabkan oleh membusuknya pangkal batang sehingga tanaman menjadi layu dan mati ${ }^{25,26]}$. Pada bagian pangkal batang pada tanaman yang sakit ditemukan hifa jamur F. oxysporum pada jaringan xilem tanaman, menyebabkan aliran air dan nutrisi terhambat sehingga pada akhirnya tanaman akan layu dan mati ${ }^{[13]}$. 


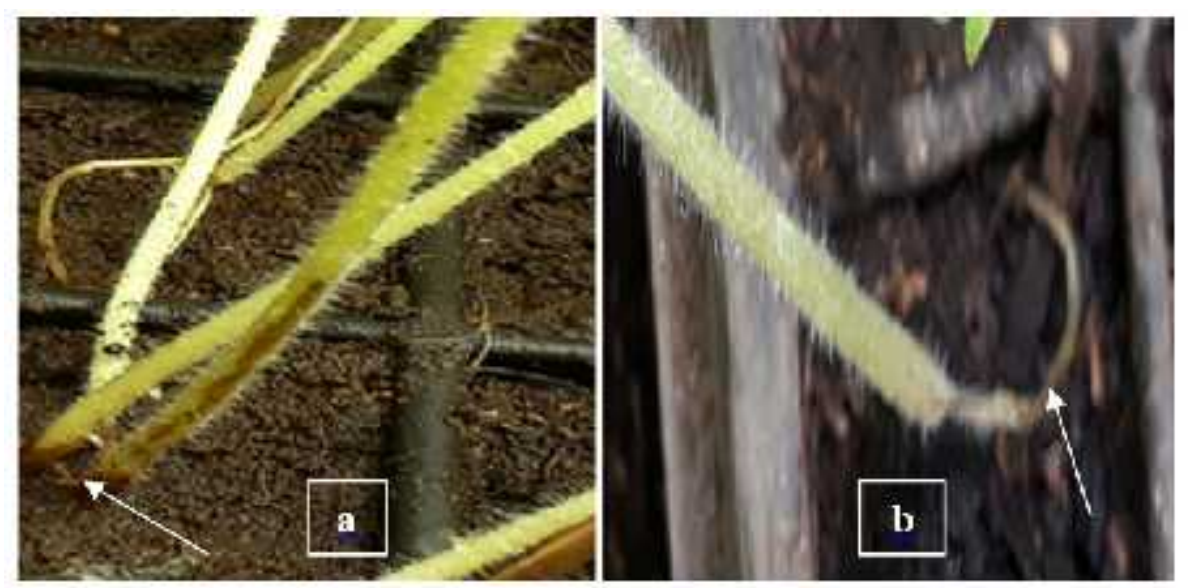

Gambar 1. Gejala penyakit layu fusarium pada persemaian tomat

(a) Pangkal batang yang berwarna cokelat,

(b) Pangkal batang yang rebah, layu dan akhirya mati

Pengamatan makroskopik pertumbuhan jamur yang diisolasi dari bangkal bangkat tomat yang sakit dipesemaian pada media PDA, terlihat koloni tumbuh berwarna putih kemudian berubah menjadi warna merah mudah keunguan (gambar 2a). Secara mikroskopik memiliki hifa bersekat, hialin, konidium sedikit melengkung dan meruncing pada kedua ujung konidium, relatif ramping (gambar 2b dan 2c). Deskripsi demikian sama seperti yang dimiliki jamur Fusarium oxysporum yakni miselium mulanya berwarna putih keruh, kemudian menjadi kuning pucat, merah muda pucat sampai keunguan ${ }^{[27]}$. Jamur F. oxysporum mempunyai tiga alat reproduksi, yaitu mikrokonidia (terdiri dari 1-2 septa), makrokonidia (3-5 septa) mempunyai bentuk yang khas, melengkung seperti bulan sabit, dan klamidospora ${ }^{[28]}$.
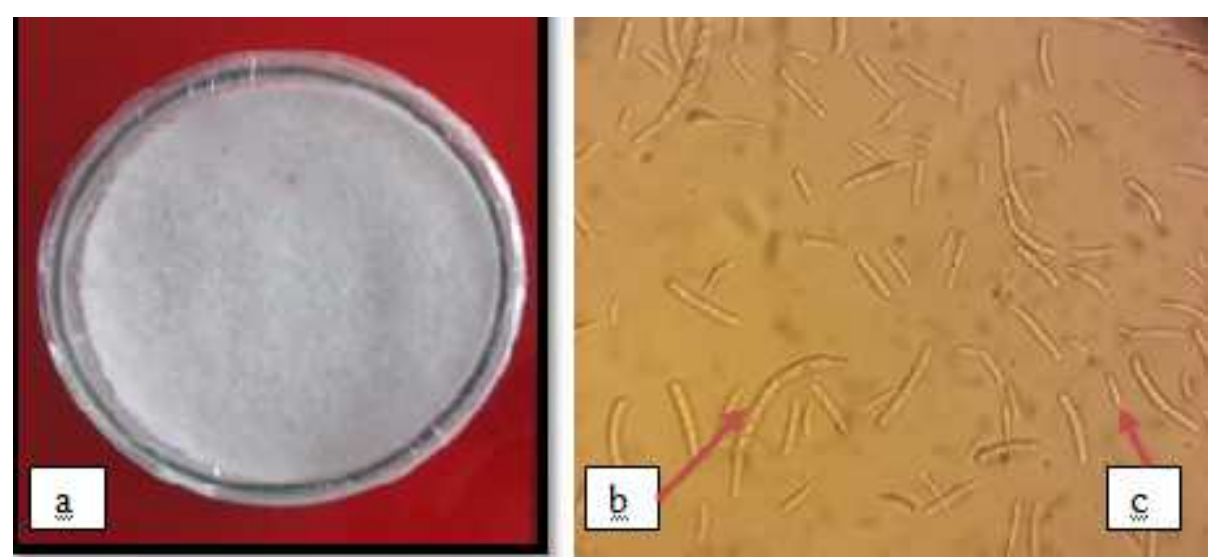

Gambar 2. Fusarium oxysporum f.sp

(a) Pertumbuhan koloni pada media PDA

(b) Makrokonidia

(c) Mikrokonidia

Pada percobaan di pot, tidak terlihat adanya gejala penyakit layu Fusarium pada

semua tanaman baik yang diberi perlakuan maupun yang tidak (kontrol), tetapi pada 
pengamatan populasi total jamur ditemukan adanya jamur Fusarium. Hal ini dapat dijelaskan bahwa perkembangan jamur Fusarium dapat dipengaruhi oleh faktor lingkungan antara lain faktor suhu dan kelembapan pada rumah plastik. Hasil pengamatan suhu dan kelembapan di rumah plastik pada siang hari selama penelitian berlangsung berkisar $26-43^{\circ} \mathrm{C}$ dan $70 \%$. Berdasarkan data suhu dan kelembapan menunjukkan bahwa ketidak munculnya penyakit di rumah plastih disebabkan karena suhu yang tinggi dan kelembaban yang rendah menghambat perkembangan Fusarium sehingga tidak mampu menyerang tanaman tomat. Perkembangan penyakit layu Fusarium membutuhkan kelembaban relatif lebih besar dari $80 \%$ dan suhu optimal berkisar $24-27{ }^{\circ} \mathrm{C}$ [29].

Faktor lain yang dapat berpengaruh sehingga pada percobaan di pot tidak terjadinya penyakit adalah ketahanan tanaman secara struktural dan biokimia pada tanaman berbeda, tergantung pada umur tumbuhan, jenis organ dan jaringan tumbuhan yang diserang, keadaan hara tumbuhan, serta kondisi iklim ${ }^{[30]}$. Ketahanan tomat diduga berkaitan dengan kandungan karbohidrat dan aktivitas enzim peroksidase yang tinggi. Karbohidrat merupakan sumber energi bagi sel untuk melangsungkan berbagai reaksi biokimia seperti aktivitas enzim peroksidase dan bahan pembangun senyawa yang berperan dalam mekanisme ketahanan tanaman. Enzim peroksidase merupakan enzim yang berperan dalam mekanisme ketahanan tanaman terhadap serangan patogen seperti F. oxysporum. Tanaman yang terserang patogen menunjukkan akumulasi peroksidase sehingga aktivitas peroksidase berhubungan erat dengan tingkat ketahanan tanaman [31]. Peroksidase mengkatalisis reaksi polimerisasi senyawa-senyawa fenolik untuk membentuk lignin. Lignin yang terbentuk dapat menghambat penetrasi jamur $F$. oxysporum sehingga tanaman lebih tahan terhadap serangan $F$. oxysporum. Dengan demikian lignin adalah produk yang dihasilkan oleh enzim peroksidase untuk menghasilkan lignin, enzim peroksidase membutuhkan substrat (prekusor lignin) berupa senyawa fenolik.

\section{Intensitas Penyakit Layu Fusarium}

Pemberian KESTA dan POC maupun NPK memberikan pengaruh signifikan terhadap intensitas penyakit layu Fusarium pada tanaman tomat dipesemaian. Efek interaksi tidak memberikan pengaruh signifikan tetapi efek mandiri dari kedua perlakuan memberikan pengaruh signifikan (Tabel 1).

Tabel 1. Pemberian Kompos KESTA dan pupuk POC maupun NPK terhadap intensitas penyakit layu Fusarium pada tanaman tomat di persemaian

\begin{tabular}{|c|c|c|c|c|}
\hline Perlakuan & $\begin{array}{c}\text { Intensitas Penyakit } \\
(\%)\end{array}$ & \multicolumn{3}{|c|}{$\begin{array}{l}\text { Penurunan Intensitas Penyakit } \\
\qquad(\%)\end{array}$} \\
\hline \multicolumn{5}{|l|}{ Dosis KESTA } \\
\hline 0 ton $\mathrm{ha}^{-1}\left(\mathrm{~K}_{0}\right)$ & $13,58 \mathrm{c}$ & - & & \\
\hline 15 ton $\mathrm{ha}^{-1}\left(\mathrm{~K}_{1}\right)$ & $11,43 \mathrm{~b}$ & 15,83 & - & \\
\hline 30 ton $\mathrm{ha}^{-1}\left(\mathrm{~K}_{2}\right)$ & $10,17 b$ & 25,11 & 11,02 & - \\
\hline 45 ton $\mathrm{ha}^{-1}\left(\mathrm{~K}_{3}\right)$ & 5,17 a & 61,92 & 54,76 & 49,16 \\
\hline \multicolumn{5}{|l|}{ Jenis Pupuk } \\
\hline Tanpa Pupuk $\left(\mathrm{P}_{0}\right)$ & $11,48 \mathrm{~b}$ & - & & - \\
\hline $\operatorname{POC}\left(\mathrm{P}_{1}\right)$ & 9,95 a & 13,32 & - & - \\
\hline $\mathrm{NPK}\left(\mathrm{P}_{2}\right)$ & 8,83 a & 23,08 & 11,25 & - \\
\hline
\end{tabular}

Keterangan : Angka yang diikuti oleh huruf yang tidak sama pada kolom dari masing-masing perlakuan menunjukkan perbedaan yang signifikan menurut uji DMRT 0,05. 
Kaya et al, 2020. Pengaruh Pupuk Hayati ...

Data pada Tabel 1 memperlihatkan bahwa intensitas penyakit terendah terdapat pada perlakuan 45 ton KESTA ha-1, dapat mengurangi intensitas penyakit layu Fusarium sampai $61,92 \%$, dan berkurangnya secara signifikan berbeda dengan perlakuan 15 dan 30 ton. Pada perlakuan pupuk, meskipun pemberian pupuk NPK dapat mengurangi intensitas penyakit sebesar 23,08 \% tetapi tidak berbeda signifikan dengan perlakuan pemberian pupuk POC (13,32 \%), tetapi keduanya memiliki pengaruh berbeda secara signifikan jika dibandingkan dengan tidak memberikan pupuk.

Pengaruh KESTA akan lebih baik jika diberikan dengan dosis 45 ton/ha, sedangkan jenis pupuk POC dan NPK sama-sama baik untuk menekan intensitas penyakit layu Fusariun. Hal ini menunjukkan bahwa Trichoderma dan Azotobacter yang terdapat dalam KESTA mampu mengendalikan perkembangan patogen $F$. oxysporum penyebab penyakit layu Fusarium pada tanaman tomat dipersemaian.

Pada dasarnya aplikasi KESTA sejak di pesemaian diharapkan dapat memberikan peluang kepada jamur Trichoderma untuk mengkolonisasi jaringan perakaran tanaman sebelum infeksi patogen. Pemberian kompos plus pada saat persemaian dengan dosis $40 \mathrm{~g}$ dapat menekan penyakit layu fusarium sebasar $77,2 \%$ sampai $87,7 \%{ }^{[26]}$, tanaman cukup mendapat kalium sehingga mempercepat penyembuhan luka, sehingga menyebabkan infeksi patogen menjadi berkurang ${ }^{[32]}$. Keadaan tersebut menunjukkan bahwa aplikasi KESTA dengan dosis 45 ton ha ${ }^{-1}$ dan POC maupun NPK sama-sama dapat menekan perkembangan penyakit layu Fusarium pada tanaman tomat di persemaian.

Peranan Trichoderma dalam menghambat patogen melalui mekanisme mikroparasitisme, antibiosis, kompetisi nutrisi, induksi dan resistensi tanaman, melarutkan nutrisi anorganik dan inaktivasi enzim patogen. Mekanisme mikroparasitisme berperan penting untuk menghancurkan dinding sel patogen ${ }^{[33]}$. Azotobacter berperan dalam mengontrol penyakit tanaman melalui substansi yang dihasilkan [34]. Azotobacter dapat memproduksi metabolit sekunder dan zat anti mikroba yang memiliki aktivitas antagonis terhadap jamur fitopatogenik dan bakteri yang menyebabkan penyakit pada tanaman [35]. Selain itu Azotobacter dapat menghasilkan siderofor, yang berpotensial sebagai agens antagonis ${ }^{[36]}$.

Pemberian NPK berpengaruh mengurangi intensitas penyakit layu pada tanaman tomat di pesemaian karena mengandung unsur hara makro $(15 \% \mathrm{~N}, 15 \%$ $\mathrm{P}, 15 \% \mathrm{~K})$ yang dapat menyediakan nutrisi untuk meningkatkan pertumbuhan tanaman dan menginduksi ketahanan tanaman baik secara struktural maupun biokimia. Ketersedian unsur hara yang dibutuhkan oleh tanaman pada media tanam dapat membuat tanaman menjadi sehat sehingga tidak mudah terserang patogen ${ }^{[13]}$. Ketahanan dapat terjadi karena kemampuan tanaman untuk membentuk srtuktur-struktur tertentu seperti pembentukan jaringan dengan sel-sel yang berdinding gabus segera setelah patogen memasuki jaringan tanaman atau adanya produksi bahan-bahan toksik didalam jaringan yang cukup banyak sebelum atau sesudah patogen memasuki jaringan menyebabkan penyakit [37]. Kemungkinan yang bisa menjelaskan pengaruh POC terhadap intensitas penyakit adalah disebakan oleh adanya mikroba yang terdapat dalam bioaktivator EM4 yang digunakan untuk pembuatan POC seperti Lumbricus (bakteri asam laktat) serta sedikit bakteri foto sintetik, Actinomycetes, Streptomyces sp., dan ragi. Effective Microorganisme (EM4) dapat meningkatkan fermentasi bahan organik, meningkatkan ketersediaan unsur hara untuk tanaman, serta menekan aktivitas serangga hama, dan mikroorganisme patogen ${ }^{[38]}$. 


\section{Tinggi Tanaman}

Pemberian KESTA dan POC maupun NPK memberikan pengaruh signifikan terhadap tinggi tanaman tomat pada umur 28 HST dipesemaian dan pada umur 35 HST di pot. Pada percobaan di pesemaian, efek interaksi tidak memberikan pengaruh signifikan tetapi efek mandiri dari kedua perlakukan memberikan pengaruh signifikan (Tabel 2). Sedangkan pada percobaan di pot, terdapat efek interaksi (Tabel 3).

Tabel 2. Pemberian KESTA dan POC maupun NPK terhadap terhadap tinggi tanaman tomat pada umur 28 HST di persemaian

\begin{tabular}{|c|c|c|c|c|}
\hline Perlakuan & $\begin{array}{l}\text { Tinggi Tanaman } \\
(\mathrm{cm})\end{array}$ & \multicolumn{3}{|c|}{$\begin{array}{c}\text { Peningkatan Tinggi Tanaman } \\
(\%)\end{array}$} \\
\hline \multicolumn{5}{|c|}{ Dosis Kompos (KESTA) } \\
\hline 0 ton $\mathrm{ha}^{-1}(\mathrm{~K} 0)$ & 16,76 a & - & & \\
\hline 15 ton $\mathrm{ha}^{-1}\left(\mathrm{~K}_{1}\right)$ & $19,35 \mathrm{~b}$ & 15,45 & - & \\
\hline 30 ton $\mathrm{ha}^{-1}\left(\mathrm{~K}_{2}\right)$ & $21,33 \mathrm{c}$ & 27,26 & 10,23 & - \\
\hline 45 ton $\mathrm{ha}^{-1}\left(\mathrm{~K}_{3}\right)$ & $24,50 \mathrm{~d}$ & 46,18 & 26,61 & 14,86 \\
\hline \multicolumn{5}{|l|}{ Jenis Pupuk } \\
\hline Tanpa Pupuk $\left(\mathrm{P}_{0}\right)$ & 19,30 a & - & & \\
\hline $\operatorname{POC}\left(\mathrm{P}_{1}\right)$ & $20,25 \mathrm{a}$ & 4,92 & - & \\
\hline $\operatorname{NPK}\left(\mathrm{P}_{2}\right)$ & $21,90 \mathrm{~b}$ & 13,47 & 8,14 & - \\
\hline
\end{tabular}

Keterangan: Angka yang diikuti oleh huruf yang tidak sama pada kolom dari masing-masing perlakuan menunjukkan perbedaan yang signifikan menurut uji DMRT 0,05.

Tabel 3. Pemberian kompos KESTA dan pupuk POC maupun NPK terhadap terhadap tinggi tanaman tomat pada umur 35 HST di pot

Dosis KESTA

\begin{tabular}{|c|c|c|c|}
\hline & $\begin{array}{c}\text { Tanpa Pupuk } \\
\left(\mathrm{P}_{0}\right)\end{array}$ & $\begin{array}{c}\mathrm{POC} \\
\left(\mathrm{P}_{1}\right)\end{array}$ & $\begin{array}{c}\mathrm{NPK} \\
\left(\mathrm{P}_{2}\right) \\
\end{array}$ \\
\hline $0\left(\mathrm{~K}_{0}\right)$ & $\begin{array}{c}90,00 \mathrm{a} \\
\mathrm{A}\end{array}$ & $\begin{array}{c}95,00 \mathrm{a} \\
\mathrm{A}\end{array}$ & $\begin{array}{c}106,33 \text { a } \\
\text { B }\end{array}$ \\
\hline 15 ton $\mathrm{ha}^{-1}\left(\mathrm{~K}_{1}\right)$ & $\begin{array}{c}109,66 \mathrm{~b} \\
\mathrm{~B}\end{array}$ & $\begin{array}{c}96,66 \text { a } \\
\text { A }\end{array}$ & $\begin{array}{c}111,00 \mathrm{a} \\
\mathrm{B}\end{array}$ \\
\hline 30 ton $\mathrm{ha}^{-1}\left(\mathrm{~K}_{2}\right)$ & $\begin{array}{c}113,33 \mathrm{~b} \\
\mathrm{~A}\end{array}$ & $\begin{array}{c}112,66 \mathrm{~b} \\
\mathrm{~A}\end{array}$ & $\begin{array}{c}110,66 \mathrm{a} \\
\mathrm{A}\end{array}$ \\
\hline 45 ton $\mathrm{ha}^{-1}\left(\mathrm{~K}_{3}\right)$ & $\begin{array}{c}113,33 \mathrm{~b} \\
\mathrm{~A}\end{array}$ & $\begin{array}{c}114,00 \mathrm{~b} \\
\mathrm{~A}\end{array}$ & $\begin{array}{c}115,33 \text { a } \\
\mathrm{A}\end{array}$ \\
\hline
\end{tabular}

$\overline{\text { Keterangan: Angka yang diikuti oleh huruf yang tidak sama pada kolom maupun baris dari masing-masing }}$ perlakuan menunjukkan perbedaan signifikan menurut uji DMRT 0,05. Huruf biasa dibaca vertikal, sedangkan huruf kapital dibaca horisontal.

Data pada Tabel 2 memperlihatkan bahwa pemberian KESTA dengan dosis 45 ton $\mathrm{ha}^{-1}$ merupakan dosis terbaik karena dapat meningkatkan tinggi tanaman tomat pada umur 28 HST dipesemaian, dan pengaruhnya berbeda secara signifikan dengan dosis yang lebih rendah, atau dapat meningkatkan tinggi tanaman sebesar $46,18 \%, 26,61 \%$ dan 14,86 $\%$ masing-masing terhadap perlakuan tanpa pupuk, 15, dan 30 ton KESTA ha ${ }^{-1}$. Sedangkan 
untuk perlakuan pupuk, pemberian NPK lebih baik dibandingkan dengan pemberian POC. Pemberian NPK dapat meningkatkan tinggi tanaman sebesar $13,47 \%$ dan $8,14 \%$ masingmasing dibandingkan dengan perlakuan tanpa pupuk dan pemberian POC.

Data pada Tabel 3 memperlihatkan bahwa pemberian KESTA dengan dosis 15 ton $\mathrm{ha}^{-1}$ sudah mampu meningkatkan tinggi tanaman jika tidak diaplikasikan dengan POC atau NKP. Jika aplikasi KESTA dengan POC, efektifitasnya lebih signifikan jika diberikan dengan dosis 30 ton/ha. Sedangkan jika diaplikasikan dengan NPK, penambahan KESTA sampai dengan dosis 45 ton ha ${ }^{-1}$ tidak memberikan pengaruh signifikan pada pengamatan tinggi tanaman.

\section{Bobot Segar dan Bobot Kering Tanaman}

Pemberian KESTA dan POC maupun NPK memberikan pengaruh signifikan terhadap bobot segar dan bobot kering tanaman pada umur 28 HST di persemaian. Ada efek interaksi yang memberikan pengaruh signifikan (Tabel 4 dan Tabel 5).

Tabel 4. Pemberian KESTA dan POC maupun NPK terhadap bobot segar tanaman tomat di persemaian

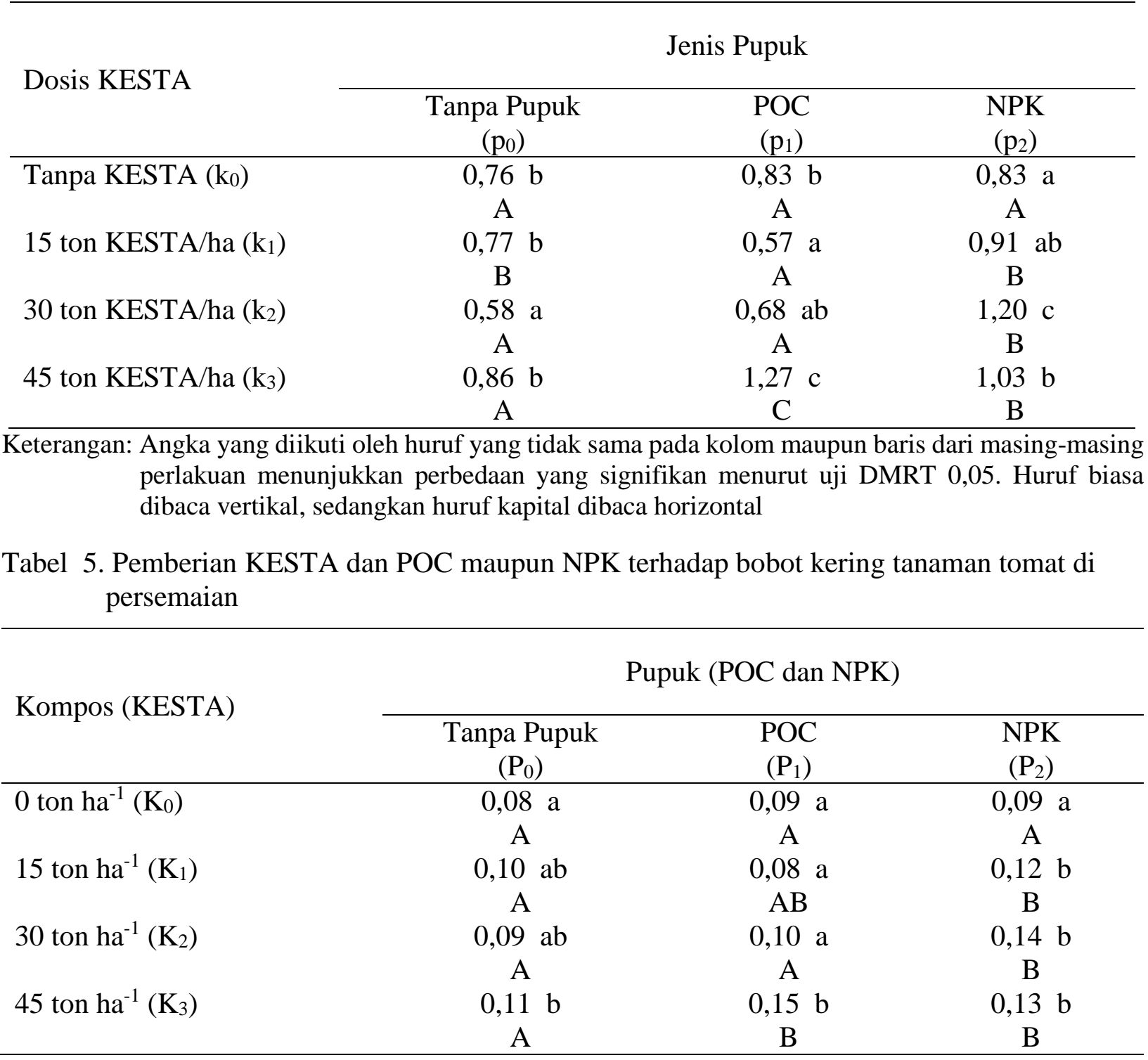


Keterangan: Angka yang diikuti oleh huruf yang tidak sama pada kolom maupun baris dari masing-masing perlakuan menunjukkan perbedaan signifikan menurut uji DMRT 0,05. Huruf biasa dibaca vertikal, sedangkan huruf kapital dibaca horisontal

Pada Tabel 4 terlihat bahwa pada percobaan di pesemaian, pemberian KESTA dengan dosis 30 ton $\mathrm{ha}^{-1}$ akan efektif terjadi jika pemberiannya dengan NPK, tetapi jika pemberiannya dengan POC harus meningkatkan dosis sampai 45 ton $\mathrm{ha}^{-1}$, terlihat pada pengamatan bobot segar tanaman. Pada pengamatan bobot kering tanaman (Tabel 4), peningkatan dosis KESTA sampai 45 ton ha ${ }^{-1}$ baru akan efektif jika pemberiannya dengan POC, tetapi jika pemberiannya dengan NPK cukup diberikan 15 ton $\mathrm{ha}^{-1}$.

Secara umum dari data yang ditampilkan pada Tabel 4 dan Tabel 5 menunjukkan bahwa KESTA dengan dosis 45 ton $\mathrm{ha}^{-1}$ lebih efektif jika diberikan dengan POC atau diberikan dengan NPK. Unsur hara makro maupun mikro serta kandungan bahan organik dan $\mathrm{pH}$ merupakan faktor yang dominan berpengaruh terhadap pertumbuhan tanaman. Hasil analisis tanah sebelum penelitian, KESTA, dan POC seperti terlihat pada Tabel 6 menunjukkan bahwa semua komponen yang dianalisis pada KESTA memenuhi standar berdasarkan Permentan Nomor 70/Permentan/SR.140/10/2011 $1^{[39]}$, sedangkan pada POC tidak memenuhi standar berdasarkan Permentan. Hal ini dapat dijelaskan bahwa kandungan kimia pada POC yang tergolong rendah sehingga kontribusi terhadap pertumbuhan dan hasil tanaman tomat di pot lebih rendah dibandingkan dengan pemberian NPK.

Tabel 6. Kandungan unsur kimia pada Tanah, KESTA, POC dan NPK yang digunakan dalam penelitian

\begin{tabular}{lcccc}
\hline Komponen analisis & Tanah awal & KESTA & POC & NPK \\
\hline C organik $(\%)$ & 29,00 & 19,69 & 0,59 & - \\
N total $(\%)$ & 0,22 & 1,20 & 0,42 & 15 \\
C/N & 13 & 16,41 & 1,40 & - \\
P tersedia $(\mathrm{ppm})$ & 5,0 & - & - & - \\
P total $(\%)$ & - & 4,64 & 0,02 & 15 \\
K tersedia (ppm) & 60 & - & - & - \\
K total $(\%)$ & - & 1,0 & 0,34 & 15 \\
pH & 6,0 & 7,9 & 5,0 & - \\
\hline
\end{tabular}

Kontribusi dari NPK karena terdapat unsur $\mathrm{N}$, $\mathrm{P}$, dan $\mathrm{K}$ mendukung proses fotosintetis dan produksi fotosintat yang dihasilkan, serta meningkatkan pertumbuhan tanaman. Tanaman dapat tumbuh dengan subur apabila elemen (unsur hara) yang dibutuhkannya cukup tersedia terutama tersedia dalam bentuk yang dapat diserap oleh tanaman ${ }^{[40]}$. Unsur hara makro dan mikro yang diberikan melalui pemupukan dapat memberikan hasil yang tinggi ${ }^{[41]}$. Hasil penelitian lainnya juga menunjukkan bahwa pemberian pupuk majemuk NPK 15-15-15 dosis $1.000 \mathrm{~kg} \mathrm{ha}^{-1}$ memberi pengaruh terbaik terhadap tinggi tanaman, serapan $\mathrm{N}, \mathrm{P}$, dan $\mathrm{K}$, bobot basah dan kering tanaman serta hasil buah tomat ${ }^{[11]}$.

Peranan utama nitrogen bagi tanaman adalah untuk merangsang pertumbuhan secara keseluruhan, khususnya batang, cabang dan daun; berperan penting dalam pembentukan hijau daun yang sangat berguna dalam proses fotosintesis, dan pembentukan protein, lemak, dan berbagai persenyawaan organik lainnya 
${ }^{\text {[42] }}$. Peranan fosfor $(\mathrm{P})$ bagi tanaman adalah merangsang pertumbuhan akar, khususnya akar benih dan tanaman muda; berfungsi sebagai bahan mentah untuk pembentukan sejumlah protein tertentu; membantu asimilasi dan pernafasan; serta mempercepat pembungaan, pemasakan biji dan buah. Sedangkan peranan kalium (K) adalah membantu pembentukan protein dan karbohidrat; berperan dalam memperkuat tubuh tanaman agar daun, bunga, dan buah tidak mudah gugur; dan juga merupakan sumber kekuatan bagi tanaman dalam menghadapi kekeringan dan penyakit ${ }^{[43]}$.

Data yang ditampilkan pada Tabel 1 sampai dengan Tabel 5 juga menunjukkan bahwa penambahan dosis KESTA baik diberikan dengan POC maupun NPK memberikan pengaruh meningkatkan pertumbuhan tomat di pesemaian maupun di pot. . Hal ini dapat dijelaskan bahwa : (1). KESTA merupakan salah satu bahan bahan ameliorant yang mengandung bahan organik, yang dapat meningkatan produktivitas tanah [44]. Pemberian bahan organik berupa kotoran ternak (pupuk kandang), bahan organik sisa panen maupun limbah hasil pertanian yang merupakan bahan pembuat KESTA dapat memperbaikan lingkungan tumbuh tanaman yang diharapkan dapat mendukung peningkatan produktivitas tanah. Bahan organik di dalam tanah diperlukan sebagai sumber energi mikroba dan mikrofauna untuk menghasilkan senyawa organik, yang diperlukan dalam proses agregasi partikel membentuk struktur tanah ${ }^{[45]}$. Peran bahan organik yang paling besar terhadap sifat fisik tanah seperti: struktur, konsistensi, porositas, daya mengikat air, dan yang tidak kalah penting adalah peningkatan ketahanan terhadap erosi [46], dan (2) KESTA mengandung Trichoderma dan Azotobacter sehingga dapat berpengaruh meningkatkan pertumbuhan dan hasil pada tanaman tomat di pesemaian maupun di pot. Hasil penelitian yang pernah dilakukan sebelumnya juga menunjukkan bahwa penggunaan Trichoderma yang diaplikasikan dengan karier kompos kotoran ayam dapat meningkatkan bobot segar tanaman sawi ${ }^{[47]}$, dan jika diaplikasikan dengan karier bokashi dapat meningkatkan pertumbuhan bibit kakao ${ }^{[16]}$.

Kemampuan Trichoderma dalam meningkatkan pertumbuhan dan hasil tanaman disebabkan karena Trichoderma dapat memproduksi bermacam enzim seperti selulase, protease, amilase, dan lipase. Enzim selulase berperan dalam perombakan selulosa menjadi glukosa, enzim protease berperan dalam perombakan protein menjadi asam amino, enzim amilase dalam perombakan karbohidrat menjadi gula sederhana, dan enzim lipase mambantu pemecahan senyawa lemak menjadi asam lemak khususnya ${ }^{[48]}$. Inokulasi Trichoderma secara langsung dapat memicu pertumbuhan dan perkembangan tanaman, karena dapat mempengaruhi produksi zat pengatur tumbuh (ZPT) tanaman, seperti auksin, Indole Acetic Acid (IAA), asam salisilik (AS), asam jasmonim (AJ) dan 1aminocyclopropane-1-carboksilase (ACC) prekursor etilen ${ }^{[49]}$.

Kontribusi Azotobacter terhadap pertumbuhan tanaman tomat di pesemaian maupun di pot adalah karena Azotobacter mempunyai kemampuan untuk menambat $\mathrm{N}_{2}$ diperakaran tanaman [21], memproduksi hormon sitokinin ${ }^{[50]}$ dan giberelin ${ }^{[51]}$ yang berperan dalam peningkatan pertumbuhan dan hasil tanaman. IAA (Indol Acetat Acid) merupakan bentuk aktif dari hormon auksin yang dijumpai pada tanaman dan berperan meningkatkan kualitas dan hasil panen. Fungsi hormon IAA bagi tanaman antara lain meningkatkan perkembangan sel, merangsang pembentukan akar baru, memacu pertumbuhan, merangsang pembungaan dan meningkatkan aktivitas enzim ${ }^{[52]}$.

Fenomena lain yang dapat dilihat dari data pada Tabel 6 adalah perbandingan hasil analisis tanah awal dan akhir penelitian. Hasil ini menunjukkan bahwa penambahan KESTA sampai 45 ton/ha yang diaplikasikan secara bersama-sama dengan penambahan POC maupun NPK tidak meningkatkan nilai $\mathrm{N}$ Total tetapi nilai K-tersedia terjadi 
peningkatan. Hal ini dapat dijelaskan bahwa kurangnya $\mathrm{N}$ dapat disebabkan karena $\mathrm{N}$ di dalam tanah dapat dimanfaatkan oleh tanaman maupun mikroorganisme. Unsur $\mathrm{N}$ sangat dibutuhkan untuk pertumbuhan jamur dan bakteri, terutama untuk perkembangan spora dan berperanan penting dalam pembentukan asam amino dan senyawa organik ${ }^{[53]}$.

\section{KESIMPULAN}

Aplikasi kompos ela sagu yang diperkaya dengan Trichoderma dan Azotobacter (KESTA), pupuk POC, dan pupuk NPK memberikan pengaruh mengurangi intensitas penyakit layu fusarium, peningkatan tinggi tanaman, bobot segar tanaman, bobot kering tanaman tomat yang ditanam pada tanah terinfeksi Fusarium oxysporum di persemaian maupun di pot. Dosis KESTA yang paling efektif adalah 45 ton $\mathrm{ha}^{-1}$, karena dapat mengurangi intensitas penyakit sampai $61,92 \%$. Sedangkan Jenis pupuk NPK dan POC masing-masing dapat menurunkan intensitas penyakit sebesar 23,08 $\%$ dan $13,32 \%$. Pemberian KESTA 45 ton ha 1 jika diberikan dengan POC efektif berpengaruh meningkatkan pertumbuhan vegetatif (tinggi tanaman 35 HST di Pot, serta bobot segar dan bobot kering tanaman tomat di pesemaian) masing-masing sebesar $1.14 \mathrm{~cm}$; serta $1.27 \mathrm{~g}$ dan $0.15 \mathrm{~g}$. Pemberian KESTA 30 ton ha $^{-1}$ jika diberikan dengan NPK efektif berpengaruh meningkatkan pertumbuhan vegetatif (bobot segar dan bobot kering tanaman tomat di pesemaian) masing-masing sebesar $1.20 \mathrm{~g}$ dan $0.14 \mathrm{~g}$, sedangkan KESTA 45 ton $\mathrm{ha}^{-1}$ diberikan dengan NPK meningkatkan tinggi sebanyak $1.15 \mathrm{~cm}$ pada tanaman 35 HST di pot.

\section{DAFTAR PUSTAKA}

[1] Suraniningsih. 2010. Mari Berkebun Tomat. CV Sinar Cemerlang Abadi, Jakarta.

[2] Badan Pusat Statistik, 2016. Provinsi Maluku Dalam Angka.
[3] Samekto, R. 2008. Pemupukan., Yogyakarta: PT Citra Aji Parama

[4] Hanafiah, K. A. 2012. Dasar - Dasar Ilmu Tanah. PT Raja Grafindo Persada: Jakarta. 360 halaman.

[5] Kaya, E. 2010. Ketersediaan Fosfat, dan Hasil Tanaman Jagung (Zea Mays L.) Akibat Pemberian Bokasi Ela Sagu dengan Pupuk Fosfat pada Ultisols. Jurnal Ilmu Tanah dan Lingkungan 9: 30-36.

[6] Kalay, A.M dan F.W. Wijayanti. 2011. Pengaruh Bokelas dan Pupuk Kandang Terhadap Hasil Kacang Tanah (Arachis hypogeal. L). Agriminal 1(1) : 28-32.

[7] Talahaturuson, A. 2015. Efek Pemberian Bokelas Plus dan Agens Hayati (Trichoderma harzianum dan Azotobacter chroococccum) Terhadap Pertumbuhan Tanaman dan Serangan Penyakit Busuk Daun Pada Sawi (Brassica juncea L).Tesis.

[8] Maryanto dan Rahmi, A. 2013. Pengaruh Jenis dan Dosis Pupuk Organik terhadap Pertumbuhan dan Hasil Tanaman Tomat (Lycopersicum esculentum) Varietas Permata. Jurnal AGRIFOR Volume XIV.

[9] Maharani, B. R., 2013. Pengaruh Pemberian Pupuk Hayati (Biofertilizer) Dan Media Tanam Terhadap Pertumbuhan Dan Produksi Tanaman Tomat (Lycopersicum esculentum Mill.), Skripsi, Departemen Biologi, Fakultas Sains dan Teknologi, Universitas Airlangga, Surabaya.

[10] Litbang, 2011. http://yogya. litbang. pertanian.go.id/ind/index.

hp?option=com_ content \&view= article\&id=706: budidaya-tomat\&catid=14:alsin [17/09/2017].

[11] Subhan, N., Nurtika, dan N. Gunadi. 2007. Respons Tanaman Tomat terhadap Penggunaan Pupuk Majemuk NPK 1515-15 pada Tanah Latosol pada Musim Kemarau. J. Hort. 19(1):40-48.

[12] Borrero, C., M.I. Trillas, J. Ordovas, J.C. Tello, and M. Aviles. 2004. Predictive 
Factors for the Suppression of Fusarium wilt of Tomato in Plant Growth Medium. Phytophatology 94(10) : 1094 -1101.

[13] Semangun, H. 2007. Penyakit-penyakit Tanaman Hortikultura di Indonesia. Edisi Kedua.Gajah Mada University Press.

[14] Novita, T. 2011. Trichoderma sp. dalam Pengendalian Penyakit Layu Fusarium pada Tanaman Tomat. Biospecies, 4 (2) : 27 - 29 .

[15] Kalay, A.M., Uluputty M.R.., Leklioy J.M.A., Hindersah, R. dan A. Talahaturuson. 2016. Aplikasi Pupuk Hayati Konsorsium dan Inokulan Padat Trichoderma harzianum terhadap Produktifitas tanaman sawi pada lahan terkontaminasi Rhizoctonia solani. Jurnal Agrologia Volume 5 hal: 78-76.

[16] Kalay, A.M., A. I. Latupapua., dan H. Talahatu. 2015. Efek Aplikasi Trichoderma sp. dan Bokasi terhadap Pertumbuhan Bibit Kakao yang ditanaman pada tanah Terinfeksi Phytophthora palmivora. Jurnal Agroekoteknologi 7(1): 75-87.

[17] Kalay, A.M. 2006. Pengujian tiga Spesies Jamur Sebagai Agens Pegendali Globodera rostochiensis (Woll). J. Peng. Wil. 2:116-121.

[18] Kalay, A.M. dan A. Talahaturuson. 2014. Perbanyakan Trichoderma harzianum pada Media Berbasis Ela Sagu. Jurnal Agroekoteknologi 6(2) : 105-113.

[19] Hindersah, R., A.M. Kalay., A. Jacob., A. Talahaturuson. 2014. Potensi Lokal Untuk Media Pupuk Hayati. Jurnal Agroekoteknologi 6 (1): 74-82.

[20] Uruilal, C., Kalay, A.M., Kaya, E dan A. Siregar. 2012. Pemanfaatan Ela sagu, Sekan, dan Dedak Sebagai Media Perbanyakan Agens Hayati Trichoderma harzianum Rifai. Jurnal Agologia 1: 2130.

[21] Simanungkalit, R.D.M., Suriadikarta, D.A., Saraswati, R., D dan W. Hartatik. 2006. Pupuk Organik dan Pupuk Hayati:
Organic Fertilizer and Biofertilizer. Balai Besar Litbang Semberdaya Lahan Pertanian, Badan Penelitian dan Pengembangan Pertanian.

[22] Hindersah, $R$ dan T. Simarmata. 2004."Potensi Rizobakteri Azotobacter dalam Meningkatkan Kesehatan Tanah". Jurnal Natur Indonesia. 5(2), 127-133.

[23] Al-Azawi, A.O., Nawar, H.H and M.I. Abdulla. 2012. Biocontrol of Fusarium oxysporum f.sp lycopersisi by plant growth promoting bacteria on tomato plant. The $2^{\text {nd }}$ Scientific Conference the Collage of Agriculture. Ministry of Science \& Technology/Directorate of Agricultural Researches.

[24] Ogbomo, L.K.E. 2011. Comparison of growth, yield performance and profitability of tomato (Solanum lycopersicon) under different fertilizer types in humid forest ultisols. Int. Res. $J$. Agric. Sci. Soil Sci. 1(8): 332-338.

[25] Lusiati. 2017. Uji Ketahanan Tomat F1 dari Parental Terpapar Medan magnet 0,2 mT dan di Infeksi Fusarium oxysporum terhadap Serangan Penyakit Layu Fusarium. Tesis.

[26] Istifadah, N., Sunarto, T., Kartiwa, D.E., dan D. Herdiyanto. 2008. Kemampuan Kompos Plus dalam menekan penyakit layu Fusarium (Fusarium oxysporum) pada Tanaman Tomat. Jurnal Agrikultura. ISSN 0853-2885.

[27] Agrios, G. N. 2005. Plant Pathology. 5th ed. New York: Academic Press.

[28] Amini, J. 2009. Physiological Race of Fusarium oxysporum in Kurdistan Province of Iran and reaction of Some Tomato Cultivars to Race 1 of Pathogen. Plant Pathology Journal, 8:68-73.

[29] Gunadi, R. 1997. Pengaruh iklim terhadap perkembangan penyakit layu Fusarium pada cabai di beberapa topoklimat di Yogyakarta. Jurnal Perlindungan Tanaman Indonesia. 3(2):93-99.

[30] Siregar, MS. 2012.Pertahanan Metabolik Dan Enzim Litik Dalam 
Mekanisme Resistensi Tanaman Terhadap Serangan Patogen.Program Ilmu Kehutanan Fakultas Pertanian Universitas Sumatera Utara. Medan

[31] Agrawal, A., Sadie,T., dan Elizabeth, B. 1999. Induced Plant defense Against Pathogens and Herbivors, Biochemistry, Ecology and Agriculture. APS Press. St. Paul, Minnesota.

[32] Dhalimi, A. 2003. Pengaruh sekam dan abu sekam terhadap pertumbuhan dan kematian tanaman panili (Vannila planifolia Andrews) di pembibitan. Buletin TRO 14(2):46-57

[33] Harman, G. E. 2006. Overview of mechanism and uses of Trichoderma spp. Phytopathology 94:190-194.

[34] Kasa, P., Modugapalem H. and K. Battini. 2015. Isolation, screening, and molecular characterization of plant growth promoting rhizobacteria isolates of Azotobacter and Trichoderma and their beneficial activities. J Nat Sci Biol Med. 6(2): 360-363

[35] Al-Azawi, A.O., Nawar, H.H and M.I. Abdulla. 2012. Biocontrol of Fusarium oxysporum f.sp lycopersisi by plant growth promoting bacteria on tomato plant. The $2^{\text {nd }}$ Scientific Conference the Collage of Agriculture. Ministry of Science \& Technology/Directorate of Agricultural Researches.

[36] Vikhe, P.S. 2014. Azotobacter spesies as a Natural Plant Hormone Synthesizer. Res. J. Recent. Sci. Vol. 3(IVC) : 59-63.

[37] Wiratama IDM, Sudiarta IP, Sukewijaya IM, Sumiartha K, Utama SMS, 2013. Kajian Ketahanan Beberapa Galur dan Varietas Cabai Terhadap Serangan Antraknosa di Desa Abang Songan Kecamatan Kintamani Kabupaten Bangli. E-Jurnal Agroekoteknologi Tropika. 2(2): 71-81.

[38] Indriani, Y.H. 2003. Membuat Kompos Secara Kilat. Penebar Swadaya. Jakarta.

[39] Peraturan Menteri Pertanian Nomor 70/Permentan /Sr.140/10/2011 Tentang
Pupuk Organik, Pupuk Hayati Dan Pembenah Tanah.

[40] Dwidjoseputro, D. 1988. Pengantar Fisiologi Tumbuhan. Gramedia, Jakarta.

[41] Prihmantoro, H. 2007. Memupuk Tanaman Sayuran. Penebar Swadaya, Jakarta

[42] Lingga, P. 2008. Petunjuk Penggunaan Pupuk. Jakarta: Penebar Swadaya.

[43] Hendaryono, D.P.S dan Wijayani. 2011. Teknik Kultur Jaringan, Kanikus, Yogyakarta.

[44] Herdiyantoro, 2008. Fauna Tanah dan Peranannya dalam Ekosistem Tanah. Laboratorium Biologi dan Bioteknologi Tanah. Jurusan Tanah Fakultas Pertanian Universitas Padjadjaran.

[45] Jian-bing, Z., Y. Jing-song, Y. Rongjiang, Y. Shi-peng, L. Furong, and $\mathrm{H}$. Xiao-jing. 2013. The effects of farmyard manure and mulch on soil physical properties in a reclaimed coastal tidal flat salt-affected soil. Journal of Integrative Agriculture. Advanced Online Publication. 14p

[46] Munawar, A. 2011. Kesuburan Tanah dan Nutrisi Tanaman. IPB Press.

[47] Kalay, A.M., Reginawanti Hindersah., A. Talahaturuson., and A. I. Latupapua 2017. Dua Inoculation of Azotobacter chroococcum and Trichoderma harzianum to Control Leaf Blight (Rhizoctonia solani) and Increase Yield of Choy Sum. International Journalof Scientific \& Engineeering Research Volume 8:1288-1292.

[48] Kullnig, C., Mach, R.L., Lorito, $\mathrm{M}$ and C.P. Kubicek. 2000. Enzyme Diffusion from Trichoderma atroviride $(=T$. harzianum $\mathrm{P} 1$ ) to Rhizoctonia solani is a prerequisite for triggering of Trichoderma ech24. Gene Expression before Mycoparasitic Contact Appl Environ Mikrobiol. 66(5): 2232-2234.

[49] Martinez-Medina, A.A., Alguicil, M.D.M., Pascul J.A. and S.C.M. Van Wess. 2014. Phytohormkne Profiles 
Induced by Trichoderma Isolates Corespond With Ther Biocontrol and Plant Growth-Promoting Activity on Melon Plants. Jurnal of Chemical Ecology :40(7) : 804-15.

[50] Simarmata, A., Sumarni, Y. dan D.H Arief. 2003. Teknologi bioremediasi untuk mempertahankan keberlanjutan kesehatan tanah dan produktifitas tanaman pada ekosistem lahan kering dan era pertanian ramah lingkungan di Indonesia. Makalah dipresentasikan pada Seminar Kajian Keilmuan Pertanian Program Pascasarjana Universitas Padjajdjaran. Bandung 14 Juli 2003.
[51] Wedhastri, S. 2002. Isolasi dan seleksi Azotobacter spp. Penghasil Faktor Tumbuh dan Penambat Nitrogen dari Tanah Masam. Jurnal Ilmu Tanah dan Lingkungan 3(1): 45-51.

[52] Egamberdiyeva, D. 2007. The effect of PGPR on Growth and Nutrient Uptake of Maize in Two Different Soils. Applied Soil Ecology. 36(1): 184-189.

[53] Monga, D. 2001. Effect of carbon and nitrogen sources on spore germination, biomass production and antifungal metabolites by species of Trichoderma and Gliocladium. Ind. Phytopathol., 54: 43543. 